\title{
Judicial Review of the Law on Community Organisations in Indonesia
}

\author{
Eddy Riswanto ${ }^{1}$, Riswadi ${ }^{2}$ \\ \{eddyunborr@gmail.com¹, riswadi@borobudur.ac.id ${ }^{2}$ \} \\ Universitas Borobudur, Jakarta, Indonesia ${ }^{1,2}$
}

\begin{abstract}
The Supreme Court of Indonesia is accountable for legal challenge of laws in Indonesia. This research method uses normative legal methods. The results of this study are based on expert testimony from both parties, namely the applicant and the government; administrative law in the social organisation law has the function of returning an order to the state before the violation occurs. So administrative law can be imposed on non-judicial officials.
\end{abstract}

Keywords: Judicial Review; Law; Community Organization

\section{Introduction}

Developing a country may be accomplished through such a process that begins with individual and collective understanding. which runs according to the same foundation and goals. In this case, a forum is needed to accommodate individuals in groups to carry out the values that grow and develop in society [1]. Building in a broad sense can be done in various ways and areas of life. Starting from expressing opinions about something related to the interests of the community, nation and state, and carried out through formulations or concepts on how to build a society that is free in thinking to find ideas that are embodied in the form of community organisations which of course can make the ideals of the nation. Indonesia.[2] In these organisations, the community can organise and run the following shared objectives. In building a community organisation, a movement is needed that is accommodated by an organisation that aims to build a community to achieve effective and organised results and gather and accommodate individuals in groups or organisations [3].

The implementation of community participation in building the nation is in line with Pancasila and the 1945 Constitution of the Republic of Indonesia. Based on the applicable laws and regulations, community organisations have rules in Law Number 17 of 2013 concerning Social Organisations. So that participation will run following the vision and mission of a community organisation in maintaining the interests of the nation and state. In this regard, the 1945 Constitution of the Republic of Indonesia in article 28 reads, "The freedom of association, assembly, expression of thoughts orally, in writing and so on is stipulated by law" [4].

So, in the 1945 Constitution of the Republic of Indonesia, it guaranteed to gather and unite thoughts and form a community organisation. According to Tirta Nugraha Mursitama in article 28 of the 1945 Constitution of the Republic of Indonesia, substantially four meanings 
of independence can be expressed by the community in the framework of building the nation and state, namely [5]:

a. The freedom of a person or society to associate;

b. The liberty of a person or organisation to assemble;

c. The freedom of a person or society to express opinions or thoughts verbally.

Law Number 17 of 2013 concerning Community Organisations in Article 1 states, "The definition of community organisation is an organisation established and formed by the community voluntarily based on the same aspirations, desires, needs, interests, activities, and goals to participate in development to achieve the goals of the Unitary State of the Republic of Indonesia based on Pancasila". Building a community organisation begins with public awareness, either individually or in community groups that run with the same foundation and purpose. The ideals in carrying out the goals of activities and common interests that are built with individual and group awareness that are believed to be able to solve common interests in a popular forum called community organisations, organisational forms are formed by community groups based on several similarities in activities, professions, goals and functions. Such as religion, education, culture, economy, law and so on.

According to M. Billillah and Abdul Hakim G. Nusantara said: "In general, Indonesian mass organisations reflect the awakening of middle-class awareness of poverty, social injustice and human rights issues. Now, CSOs in Indonesia can also be said to be a reflection of awareness about the impact of development programs implemented by the government and the actions it takes in implementing these programs" [6]. In Indonesia, some community organisations are engaged in positive activities by involving the community in protecting the environment, such as (Walhi), helping the community in law (LBH APIK). At the other end by playing a role whose community activities are carried out peacefully by empowering the community, on the other hand, there are as well as community organisations that carry out less commendable activities, among others what has been reported, namely the Islamic Defenders Front (FPI) which always acts in the name of religion in its activities. However, from a legal point of view, all types of vandalism and acts of violence are expressly prohibited.

The channelling of aspirations through the organisation is believed to get the attention of many parties if the form of activities is organised and directed following the goals of the community organisation because the aspirations conveyed are the aspirations of the organisation, not on behalf of themselves, and carry the interests of its members. In the context of living as a nation and state that prioritises aspects of democracy in its implementation, it is natural for new organisations to emerge because the more opportunities are opened for expressing opinions and gathering, the more open the possibility for differences of view be. Respect for differing viewpoints has ramifications for the creation of new organizational platforms. Community organizations that recognize the value of institutional struggle will be more careful in selecting a forum based on ethnic commonalities, beliefs, and other factors. The community's choice of community organization is chosen with the selfawareness of being able to engage directly in the community organization's operations. In a community organization, it is not unusual for the organization to prioritize its own group, resulting in anarchic behavior in people's lives.

According to Tirta Nugraha Musitama, "Anarchist actions in their understanding are a form of concrete response to the failure of the current legal mechanism. In overcoming problems, community organisations use their actions to follow up on problems that occur in the community. Such an action, without realising it, is an act against the law. However, on the other hand, this seems to have been left unchecked, or there is a lack of firmness from law enforcement officers over various forms of unchecked actions that have occurred so far" [7]. 
Civic groups have a place and a chance to flourish alongside democracy in all aspects of a nation's and state's existence, particularly if human rights are valued and supported by the present system. These liberties might sometimes be characterized by a lack of control and bounds. Some community groups preach and act on behalf of human rights, forgetting the essence of human rights, which is that freedom has a place and that human rights are respected. The phenomena of a group of people carrying out anarchic activities on behalf of organizations and individuals has been widely publicized in the internet and print media. This tendency is both psychologically and financially unprofitable. This means that the government must act quickly to ensure that the phenomenon of acts of violence and destruction does not develop into a new culture in society, because acts of violence and destruction are fundamentally opposed to the essence of Human Rights, whereas omissions of acts of violence and destruction are reported. Continually is a kind of legitimizing the occurrence of violence to spread across our society. If this goes unchecked, it may stimulate the growth of narrow primordialism, which will result in the rupture and shakiness of national unity, necessitating the dissolution of Community Organizations.

Law Number 17 of 2013 concerning community organisations has not regulated several articles that handle the issue of establishing community organisations. There is no precise regulation on the topic of how to dissolve community organisations and community organisations that must be dissolved. And the need for additional articles related to the absence of clear regulations regarding the mechanism for the dissolution of the community organisation. However, community organisations that follow people's lives and help the surrounding community deserve to be maintained and empowered, but some act on behalf of community organisations for their interests. These organisations can endanger people's lives, so that the organisation needs to be dissolved. The dissolution of the community organisation has been regulated in Law Number 17 of 2013 concerning Community Organisations. This means that when someone commits a lawless act, criminal law can be used as a means of prosecution.

\section{Methodology}

From the point of view of legal theory, the research method is divided into normative legal science and empirical legal science.[8] Practice law arose from the notion of positivism, whereas normative law arose from the idea of normative law. Thus, a research of the legislation could be done prescriptively or scientifically, with each having its own set of qualities and procedures. Methods and approaches for solving research issues are known as research methodologies. [9] As a result, methods of research are always tailored to the requirements of the project. This study falls under the category of normative legal research, which evaluates legislation within the context of a unified legal system. The law in this situation is a positive norm that applies at a given moment and is enacted by a legitimate political entity. [10] There is also a belief that research is normative or doctrinal when the challenges and study aims of legal studies mirror the ideal world of law (philosophical, legal precedents, legal norms, systematic logic, and basic understandings of law).

The approach used is the statutory approach, namely, reviewing and researching the laws and regulations relating to establishing and dissolution of Community Organisations in Indonesia. A conceptual approach (conceptual approach) is an approach that is carried out by reviewing the opinions of experts related to the research discussed. Path to the decision of the Majlis Hakim, which has permanent legal force (inkrah). Legal Resources: Types and 
Sources, where legal materials are classified as primary, secondary, and tertiary. Primary legal resources (primary legal resources) are legal materials that follow and are obtained from Indonesian laws and regulations relating to the formation and disbandment of Community Organizations, namely Law Number 17 of 2013 concerning Community Organizations and the rules and regulations that support the topic to be researched.

Secondary legal materials (secondary legal resources) are legal materials that provide explanations of primary legal materials such as books, research results, scientific journals, articles and so on. Tertiary legal materials (tertiary legal resources) are legal materials that can provide guidance and explanations for primary and secondary legal materials such as legal dictionaries, encyclopedias and others.

\section{Results and Discussion}

\subsection{Dissolution Of Indonesian Hizbut Tahrir Jurisdiction Of The Supreme Court Number 27 K/Tun/2019 Based On Perpu Number 2 Of 2017}

Every citizen has the right and obligation to maintain the integrity of the Unitary State of the Republic of Indonesia. Every individual has the right to protection, and the state guarantees this. Every citizen also has the right to form a group or association with other individuals, and the government ensures that through the laws and regulations of social organisations, as long as the organisation does not conflict with the existing laws and regulations, every citizen has the right to express their aspirations, either individually or collectively. Individuals and organisations where they are sheltered or community organisations freedom to express opinions in public. In this regard, Article 28 of the 1945 Constitution of the Unitary State of the Republic of Indonesia reads: "The Constitution of the Unitary State of the Republic of Indonesia guarantees the assembly and unification of minds in establishing a forum for social organization, as well as the freedom of association and assembly, as well as the expression of ideas both verbally and in writing."

Freedom in the sense that it is following the rules of social and community life because we as social beings cannot live alone, and it is mandatory that we need other people. Likewise, when individuals want to unite perceptions, discuss to connect goals, it is necessary to form a forum, in this case, community organisations as a way or instrument in achieving a goal, creating a platform called community organisation, of course, based on the applicable laws and regulations. Namely Law Number 17 of 2013, which regulates the procedures for establishing community organisations in such a way as to start with names, symbols, attributes such as flags and even the activities of the organisation itself so that the things that are done do not violate the rules and do not interfere with public order or public order. Even to the point of threatening the integrity of the Unitary State of the Republic of Indonesia.

In article 61 of the Government Regulation instead of Law of the Republic of Indonesia, Number 2 of 2017, Community Organisations imposed with administrative sanctions are a. A written warning; b. A suspension of activity; and c. The revocation of a registration certificate or the status of a legal body. More specifically, it is described in Article 62, which states that the written warning referred to in Article 61 regarding the imposition of administrative sanctions in accordance with the provisions of Perppu Number 2 of 2017 concerning Social Organizations, the written notice referred to in Article 61 paragraph (1) letter an is given only 1 (one) time. Within seven (seven) working days after the warning being given. If the mass organization fails to comply with the written notification within the time frame specified in 
paragraph (1), the Minister and the Minister in charge of government affairs in law and human rights have the jurisdiction to impose sanctions, including the suspension of activity. Assume that the mass organization does not abide by the sanction of activity stoppage alluded to in paragraph (2). In that situation, the Minister and the Minister in charge of government activities in the sphere of law and human rights will remove a legal entity's certificate of registration or status.

Suppose the community organisation does not comply with administrative sanctions up to a written warning. In that case, the local government can temporarily stop the organisation's activities. Still, suppose the community organisation is in a structural form from the national to the regional level. In that case, the government is obliged to ask for legal considerations from the Supreme Court. For this reason, the author must describe the sound of Article 59 of the Government Regulation instead of Law Number 2 of 2017 concerning amendments to Law Number 17 of 2013 regarding Social Organisations as follows. : The sound of Article 59 is amended so that the explanation is more straightforward regarding the prohibition of mass organisations, as a limitation of social organisation as stated in article 59 of the Perppu Ormas Number 2 of 2017. Paragraph (1) Ormas are prohibited from: a. Using the same name, coat of arms, flag, or attributes as the name, emblem, banner, or characteristics of a government agency; b. Using without permission the terms, symbols, flags of other countries or international institutions/agencies as the names, logos, or banners of Ormas; and c. Using a name, mark, flag or graphic sign that has similarities in essence or its entirety to the title, symbol, flag, or image of another mass organisation or political party.

Paragraph (2) Ormas are forbidden from: a. Receiving or giving money in any way to any political party in violation of the law; and b. raising funds for political parties. a. Performing acts of hostility toward ethnicity, religion, race, or class; b. Performing acts of abuse, blasphemy, or blasphemy against the religion professed in Indonesia; c. Performing acts of violence, disturbing the peace and public order, causing damage to public facilities and social facilities; and d. Performing activities that are the duties and authorities of law enforcement in accordance with the legislation. Paragraph (3) Ormas are prohibited from: a. Using the name, emblem, flag, or symbol of an organisation that has similarities in principle or its entirety to the title, logo, banner, or sign of a prohibited organisation; b. Engage in separatist actions that are critical of the Republic of Indonesia's Unitary State; or c. Adhere to, create, and promote doctrines or understandings that are opposed to Pancasila.

The Court can then dissolve community organisations that are proven guilty. Still, in this case, the problem is that community organisations can't be so easily disbanded, as is the case with the Indonesian Hizb ut-Tahrir community organisation, which often commits anarchic acts as is often reported by television media. Because Law 17 of 2013 still contains provisions that have not been adopted, the government published Regulation in Lieu of Law Number 2 of 2017 as an update to Law 17 of 2013 regulating Social Organizations. And in the law, it is not clear what mistakes are made by a community organisation so that the community organisation deserves to be dissolved and what are the criteria, this is something that has not been regulated, or the explanation of the articles in it is not clear, for example in the Perppu number 2 of 2017 article 59 paragraph 4 letter c which reads "adhering, developing, and spreading teachings or understandings that are contrary to Pancasila", not so much explained in detail the understanding that is meant so that it will lead to many perceptions and interpretations, only explaining the teachings or experiences which conflict with Pancasila, among others, the teachings of atheism, The applicant's social organization, which co-founded and promoted it, was dissolved unilaterally by the Government of the Republic of Indonesia 
for adhering to, developing, and spreading views that are antithetical to Pancasila and the basic norms of the government in lieu of law.

So, according to the author, the actions taken by the government to abolish 17 articles in Law No. 17 of 2013 were then replaced with Government Regulations instead of Law No. 2 of 2013, which removed the authority of the judiciary, the government seems to no longer trust the existing Court. To adjudicate all types of cases in Indonesia, so that the functions and authorities of the judiciary that judge a particular issue are following the source and type of claim that should have gone through the stages of the process of the government judiciary by simply using its power to take the authority of the Court even though the government is authorised by law. Laws to issue Government Regulations in place of existing laws, things that are feared as citizens under whose leadership all the powers granted by the law are misused to smoothen their interests yes, controlling things that are considered as obstacles to all forms of policy, the impression is too political, not protecting the interests of the state or maintaining the integrity of the Indonesian nation but instead protecting the interests of the authorities in issuing all forms of policies while in power.

The importance of a judicial body to be created so that every citizen can pass through the stages of the judicial process in seeking justice and law enforcement so that when a case is alleged to be against a community organisation, it is not immediately dismissed. This is because there is no court authority to assess and decide a case in question. In contrast, the possibility of community organisations accused of committing violations according to the government's assessment and deciding only leads to the government means that the case is final and has permanent legal force. This means that no legal action is taken by the party accused of committing the offence.

Legislation is made to guide community actions that can determine what is allowed and what is not. A stable law as an arena can be a definite measure in society. However, the law that runs in place, in reality, the decree will become obsolete which is left far behind by the development of society which causes a legal vacuum (emptiness of laws and regulations) on things or conditions that develop in the community which indeed have not been regulated or if it has been regulated but unclear or even incomplete or obsolete. For this reason, a stable, updated or flexible law is needed that can keep up with the times.

A formal system is legislation (positive law) that applies to a country at a specific moment. Of course, even while it no longer follows the growth of society that must be enforced during that society, it is impossible to change or cancel it. As a result, there is a void in the legal language that is still narrow, giving rise to many perceptions that things or conditions that have not been regulated can lead to legal uncertainty. The government is again issuing legislation to replace the existing laws and regulations. There is considered to be irrelevant to the situation and immediately applied as a reference to evaluate and decide a case so that the impression on the government is too rash to use its power of authority even though it is an urgent matter and urges efforts to maintain the integrity of the Unitary State of the Republic of Indonesia.

This is what causes confusion and doubt in the community regarding the policies issued by the government in the form of laws and regulations. However, Article 59 paragraph (1) regarding the prohibition for community organisations only regulates things that social organisations cannot do but does not explain and elaborate further or more broadly if the institution uses the same logo or symbol as the state, it can immediately be dissolved, it should be regarding the prohibition would be better mentioned and provide a systematic and detailed explanation so that the existing organisation already knows in detail about the things that the organisation should not do. 
Regarding community organisations that are wings of political parties, they may aim to channel the unavoidable aspirations of the people to raise funds for political parties. In today's society, many community organisations are funded by political parties and receiving funds from political parties because community organisations are formed to collect income and income from the community. In this case, it is also in the interest of political parties to include community organisations.

If there is a legal vacuum, the steps that must be taken to overcome the legal vacuum are as follows. However, the articles require clear explanations and interpretations so that the understanding or performance of the laws and regulations can be applied positively. Efforts to interpret the existing positive law can be used in every case because there are times when the law is unclear, incomplete, or may not be relevant to the times (out of date).

Based on Article 22 A.B. (Algemene bepalingen van Wetgeping voor Indonesia; Stb. 1847: 23) and Article 14 of Law Number 14 of 1970 concerning the Principles of Judicial Power, a judge may not suspend or refuse to examine a case on the pretext that the law is not perfect or there are no rules. Law. The condition of the law is sometimes incomplete or unclear because the order of social life in society changes so quickly that a judge must make legal discoveries (rechtsvinding). Legal discovery is considered a process of law formation by judges or other legal officers on concrete legal events or in different languages. Legal discovery is an effort to concretise general and abstract legal regulations based on actual events. In other words, judges must adapt the law to factual matters. Therefore, existing rules cannot cover all events that arise in society.

In addition, if a statutory regulation is unclear, the judge is obliged to interpret it so that a decision and legal certainty can be given that is genuinely fair and under the context of the incident and the purpose of the law, namely achieving legal certainty. Although judges participate in discovering the law and are required to understand the law, create rules and regulations, the position of judges is not as the holder of legislative or executive power (as the legislative-forming body) who is given the authority to make laws as the DPR and the Government (President). The judge's decision does not have the force of law, such as general regulations that apply nationally and must be used as a reference in deciding a case. The judge's decision only applies to the parties concerned. This is confirmed in chapter 21 A.B. (Algemene bepalingen van Wetgeving voor Indonesia; Stb. 1847: 23), which states that "the judge cannot give a decision that will apply as a general rule", the judge's decision is also recognised as a source of formal law, thus by the legislation admitted that the work of the judge is a law-forming factor, a judge acts as a law-former if the bill does not mention a provision to resolve a case that occurs in society. This means that judges must concretely adjust the law because the regulations do not cover all events in the community. It is further confirmed in Article 1917 of the Civil Code (BW).

\subsection{Is the Ormas Law still relevant to current conditions? Must do a judicial review}

When we talk about mass organisations. Of course, we will speak as government partners in resolving community affairs, not all of which can be resolved through bureaucratic elements. The role of mass organisations is vital in a democratic country like Indonesia, not only as partners but also as collaborative governance for government both at the centre and in the regions. If we talk about mass organisations, of course, we will speak as government partners in solving community affairs, and not everything can be resolved through the bureaucratic element. Mass organisations' role is vital in a democratic country like Indonesia, 
not only as a partner but also as a collaborative government for the government both at the centre and in the regions [11].

In this case, of course, the government also has the interest of which mass organisations can be partners for collaboration and certainly does not conflict with the ideology of the Pancasila state. Supriyanto [12] gave a more in-depth statement about mass organisations contrary to Pancasila, which can be dissolved based on Law number 17 of 2013 concerning social organisations. In the Regulation in place of Law Number 2 of 2017 on Amendments to Law Number 17 of 2013 regarding Social Organisations is the embryo of the emergence of Law Number 16 of 2017 concerning Stipulation of Government Regulations in place of Law Number 2 of 2017 concerning Amendments to Laws -Law Number 17 of 2013 regarding Community Organisations, after this referred to as the new Ormas Law. In the preamble to the new law on mass organisations, it is stated that the government in enacting the law was based on the reason that mass organisations were factually proven to have principles and activities that were contrary to Pancasila and the 1945 Constitution of the Republic of Indonesia as well as other reasons that the administrative, legal Regulation has not been fulfilled, namely the "ascontrariusactus principle" contained in Article 62 paragraph (3) of the new Ormas Law.

The article explains that the article gives full authority to the Executive to revoke the Ormas legal entity without going through a judicial mechanism first. These provisions are very subjective, significantly rubber articles (multi-interpretation). The provisions of Article 62 paragraph (3) are also emphasised by Article 80 A of the new Ormas Law.

This is seen as different from the previous regulations contained in Law Number 17 of 2013 concerning Community Organizations Article 68 in particular paragraph (2), which norms explain that the sanction of Revocation of legal entity status is imposed after a court decision has obtained permanent legal force regarding the dissolution Legal entity organisations. The principle of contrarious actus has also been attached to officials without being reaffirmed into legislation. In general, the focus of contrarious actus has been stated explicitly in Article 33 paragraph (3) of Law Number 30 of 2014 concerning Government Administration which reads:

The Government Administration Law also stipulates the criteria or limits for the government to revoke a mass organisation permit as stated in Article 64 paragraph (1), namely in the event of a defect in authority, procedure, and substance. And according to the author, the new law on mass organisations to emphasise the principle of contrarious actus normatively is not correct. In principle, the issuance of a new law on mass organisations in a press release (12/7/2020) which was conveyed by the Coordinating Minister for Political, Legal and Security Affairs, Mr Wiranto, gave the following arguments:

a. The Regulation in Lieu of Law was published as part of the government's responsibility to defend the whole country and Indonesia's territory.

b. Community organisations in Indonesia, which now number 344,039 and are involved in many aspects of life on both the regional level, should be strengthened and nurtured in order to contribute positively to nation building.

c. The reality is that currently, there are activities of community organisations (or as) that are contrary to Pancasila and the 1945 Constitution of the Republic of Indonesia. This is a threat to the existence of the nation by causing conflict in society.

d. In terms of substantive factors linked to norms, prohibitions, and consequences, as well as processes, Law Number 17 of 2013 concerning Social Organizations is no longer suitable to prevent the propagation of ideas that are opposed to Pancasila and the Republic of Indonesia's 1945 Constitution. Existing legislation. The non-application of the administrative law concept of contrarious actus, which states that the institution providing 
the permission or awarding ratification should have the capacity to revoke or cancel it, among other things.

e. So far, the concept of doctrines and acts that are antithetical to Pancasila has been restricted to Atheist, Marxist, and Communist. Other doctrines, on the other hand, may and do contradict Pancasila, as Indonesian history shows.

In light of the foregoing, the government believes it is essential to issue a Government Regulation in lieu of Law No. 2 of 2017 about Amendments to Law No. 17 of 2013 Concerning Social Organizations. Furthermore, this Perppu is a legal umbrella for the government to be more flexible in guaranteeing, empowering, and fostering mass organisations. Theoretically, in the value theory of constitutional validity put forward by Karl Loewenstein, there are three values: normative, nominal, and semantic. And the enactment of the new Ormas Law is guided by referring to a semantic value. Semantic value constitution means that the figure is legally valid but only to give form or exercise political power. The figure is just a term because its implementation must always be linked to the interests of those in power.

In the argument presented by the Coordinating Minister for Political, Legal and Security Affairs, Mr Wiranto, there is a reason that the contrarious actus principle has not been fulfilled. With the application of the principle of contrarious actus in the new Ormas Law. So the government represented by the ministry of law and human rights can revoke the legal entity status of mass organisations without going through a judicial mechanism first. This negation of the judicial process becomes a problem when the state, in this case, the government (Executive), can easily declare that mass organisations have violated what is called threatening the sovereignty of the Unitary State of the Republic of Indonesia based on Pancasila and the 1945 Constitution of the Unitary State of the Republic of Indonesia. There are no clear parameters for the violation, and it cannot be measured objectively. The new Ormas Law regulates a dissolution mechanism as a form of demolition of the right to freedom of association by allowing arbitrariness to enter into it because it is considered to be contrary to the spirit of reform and democratic principles, as well as the rule of law.

However, in its application and enforcement, the rule of law is meant to measure good and bad directions so that there is a just and unjust law. Thus, the essence of enforcing the rule of law is the guarantee of what society views as justice, especially social justice. Thus the rule of law is ensured, not only with a legal system but also with a sound judicial system, so that people can enjoy justice, in the sense of fair treatment, both from fellow citizens and their government. In other words, it is not just the existence of a law that guarantees the realisation of the rule of law. But more than that, namely the presence of justice that ensures the protection of human rights and can be enjoyed by everyone.

\section{Conclusion}

The government should provide education to apply the laws and regulations that have been issued, in this case handling disputes over community organisations regulated in the law on mass organisations, many of which deviate from Law Number 17 of 2013 in dealing with conflicts within mass organisations such as receiving registrations for mass organisations which are currently in an internal conflict within the organisation, the government, in this case, through the Menkumham, should be more observant in looking at all developing aspects so that in issuing the SK the relevant Ormas does not cause conflict again, or every mass organisation that is hostile to the Menkumham in issuing the decree refers more to the results 
of the process. Dispute courts that the courts have decided at each level must ensure that the organisation's activities are completely disabled in the case of a social organisation that is one institution that has the same two enforcement agencies or what we know as dualism. So if this is allowed to trigger the same conflict, law enforcement must respond quickly so that the turmoil that exists in the internal body of social organisations so as not to cause prolonged conflict so that actions we don't want occur, to avoid things that we don't want to happen, immediately addressed and given a peaceful and unified solution. Concerning the dissolution of government civil society organisations, the issuance of Perppu is correct, detailed and systematic, especially on the issue of sanctions so that the distance of its application can be used flexibly, can adapt to the conditions of the times, and does not create the impression of being too political in every change of government, creating a perception that only the interests of the government are perceived.

\section{References}

[1] J. Burke, "Law, politics and intelligence: a life of Robert Hope," J. Policing, Intell. Count. Terror., vol. 15, no. 2, pp. 187-188, 2020, doi: 10.1080/18335330.2020.1775278.

[2] V. Cornelis, "Kajian Yuridis Organisasi Masyarakat Pada Komitmen Kehidupan Bermasyarakat dan Bernegara di Wilayah NKRI," 2019.

[3] D. McQuail and S. Windahl, Communication models: For the study of mass communications. Routledge, 2015.

[4] M. K. Wardi, “ANALISIS YURIDIS PENDIRIAN DAN PEMBUBARAN ORMAS (Studi Kasus Putusan Sengketa Administrasi Ormas NW dan HTI),” J. Juridica, vol. 1, no. 1, pp. 15-27, 2019.

[5] Yoomeidinar, T. N. Mursitama, F. Alamsjah, and T. Rusmanto, "EFFECT OF FEMALE LEADERSHIP , BOD GENDER DIVERSITY , AND GENDER EQUALITY ON COMPETITIVE ADVANTAGE: COMPARISON OF MALE DOMINATED INDUSTRY AND NON-MALE DOMINATED," Int. J. Manag., vol. 11, no. 9, pp. 194-202, 2020, doi: 10.34218/IJM.11.9.2020.020.

[6] M. M. Billah and A. H. G. Nusantara, "Lembaga Swadaya Masyarakat di Indonesia Perkembangan dan Prospeknya," Prism. No 4, Tahun XVII. LP3ES, 1988.

[7] T. N. Mursitama, "Pengkajian Hukum Tentang Peran Dan Tanggungjawab Organisasi Kemasyarakatan Dalam Pemberdayaan Masyaraka," Jakarta Pus. Penelit. Dan Pengemb. Sist. Huk. Nas. Badan Pembin. Huk. Nas. Kementeri. Huk. Dan Hak Asasi Mns. RI, 2011.

[8] Ahmad Zuhdi, "Perkembangan Metodologi Penelitian Hukum," J. Huk. dan Perad., vol. 1, no. 2, pp. 189-206, 2012.

[9] J. D. I. Duncan and J. D. I. Duncan, Methodological Approaches. 2020.

[10] Z. D. Zaini, "Implementasi Pendekatan Yuridis Normatif dan Pendekatan Normatif Sosiologis dalam Penelitian Ilmu Hukum," Pranata Hukum, vol. 6, no. 2. pp. 117-132, 2011.

[11] “MK Putuskan Uji Materi UU Ormas," Mahkamah Konstitusi, no. Desember, p. 57854097, 2018.

[12] E. E. Supriyanto, "Revitalization of Pancasila as a Solution to The Problems Faced by The Indonesian Nation,” J. Pendidik. Nusant., vol. 1, no. 2, pp. 52-61, 2021. 